University of Texas at Tyler

Scholar Works at UT Tyler

Human Resource Development Faculty

Publications and Presentations

Human Resource Development

$1-2021$

\title{
Virtual HRD's Role in Crisis and the Post Covid-19 Professional Lifeworld: Accelerating Skills for Digital Transformation
}

\author{
Elisabeth E. Bennett \\ Northeastern University \\ Rochell McWhorter \\ The University of Texas at Tyler, rmcwhorter@uttyler.edu
}

Follow this and additional works at: https://scholarworks.uttyler.edu/hrd_fac

Part of the Human Resources Management Commons

\section{Recommended Citation}

Bennett, Elisabeth E. and McWhorter, Rochell, "Virtual HRD's Role in Crisis and the Post Covid-19 Professional Lifeworld: Accelerating Skills for Digital Transformation" (2021). Human Resource Development Faculty Publications and Presentations. Paper 19.

http://hdl.handle.net/10950/3773

This Article is brought to you for free and open access by the Human Resource Development at Scholar Works at UT Tyler. It has been accepted for inclusion in Human Resource Development Faculty Publications and Presentations by an authorized administrator of Scholar Works at UT Tyler. For more information, please contact tgullings@uttyler.edu. 
Note: This is the last authors' copy prior to publishing. The final, definitive version of this article has been published in Advances in Developing Human Resources, 23(1), 5-25. See:

https://doi.org/10.1177/1523422320973288

Virtual HRD's Role in Crisis and the Post Covid-19 Professional Lifeworld: Accelerating Skills for Digital Transformation

\author{
Elisabeth E. Bennett, \\ Northeastern University, el.bennett@,northeastern.edu \\ Rochell R. McWhorter, \\ The University of Texas at Tyler, rmowhorter@uttyler.edu
}

Keywords: virtual HRD, technology, workplace learning, pandemic, Covid-19, reskilling, upskilling 


\begin{abstract}
Problem: The Covid-19 pandemic brought unprecedented crisis to a world already undergoing digital transformation. Millions of people began working virtually to prevent the spread of disease and to maintain business continuity, suddenly participating in virtual human resource development (VHRD) and alternative work strategies that helped organizations adapt to current challenges and prepare for future disruption. The purpose of this article is to analyze VHRD's role in the crisis and the transition to a new era marked by further disruption and change.
\end{abstract}

Solution: This article provides a primer for understanding the environmental perspective of VHRD, analyzes reskilling and upskilling trends during the pandemic and for early stages of the fourth industrial revolution, and addresses learning, adaptation, cultural, workplace, and economic implications. We argue that many of the changes to the workplace were already underway, but the pandemic has accelerated transformation. For this reason, organizations must anticipate more digital transformation, strategize VHRD, and leverage learning assets to prepare for the future.

Audience: This article is of interest to those helping their organizations to not only recover from crisis, but to thrive in a new era of work that is being fundamentally transformed by technology. The audience includes organizational leaders, HRD professionals, workers, scholars, as well school personnel seeking to prepare learners for future career conditions. 


\section{Virtual HRD's Role in Crisis and the Post Covid-19 Professional Lifeworld: Accelerating Skills for Digital Transformation}

Internet-age technology has been reshaping work and learning for several decades, theorized in the field under virtual human resource development (VHRD) inquiry. More recently, Artificial Intelligence (AI) and the Internet of Things (IoT) have become disruptive drivers of change, though initially limited as the wave of technological innovation crests with new workplace skills needed to recover from disappearing jobs due to automation and economic disruption (Bennett, 2018); this groundswell requires reskilling - that is, to prepare employees for new jobs and career changes - and upskilling - that is, to prepare employees for advancing within their current career tracks. The developing Gig economy thrives on freelance work and transient, often temporary assignments with multiple clients (Istrate \& Harris, 2017), leading to questions about how to define employees and contractors, apply employment laws across multiple jurisdictions, and how to balance career flexibility with corporate aims.

Then along came a novel coronavirus: Covid-19.

Previously, VHRD conversations at conferences discussed the value of Internet and 3D technology for learning about uncommon diseases that medical personnel rarely see in practice and for a potential health crisis, such as field hospital simulation or sharing knowledge of a novel disease at the point of outbreak, a black swan event that we hoped would never materialize, but recognized the potentially catastrophic scenario. In the U.S., the impact of Covid-19 is now estimated to be $\$ 16$ trillion with a deepening economic recession involving more than 60 million unemployment claims, numbers far exceeding the 1982 downturn (Cutler \& Summers, 2020), and globally over a million lives lost. Coincidentally during this time - and perhaps due in part to distress from torn social fabric and economic hardship - civil unrest further damaged the 
business/employment apparatus and generated mounting calls for social reform.

The world experienced VHRD with technology so pivotal to business continuity and education in the pandemic. VHRD has been an area of inquiry on the outskirts moving to the center of organizational practice. The year 2020 marks the point many new employers and professionals were thrust into the world of VHRD to accommodate work-from-home mandates and alternative work strategies (Bennett, 2009). The pandemic brought new division between essential and non-essential workers, sanitation practices, lay-offs and reduced hours, supply chain interruption, rapid innovation, work-life balance issues, and disruptive modes of learning and problem-solving, not to mention a time of great anxiety and much-needed empathy for the most vulnerable. In retrospect, the world-as-we-knew-it ended with a dividing line between preand post-Covid-19 historical eras, and we are just beginning to project the post-pandemic reality at the same time as reconciling great civil conflict.

We argue in this article that many of the changes to the workplace were already underway due to digital transformation, and the pandemic simply accelerated this transition, as well as brought a few unique challenges that may eventually become extinct or remain embedded in civic culture, like social distancing. The purpose of this article is to analyze VHRD's role in the crisis and the transition to a new era marked by further disruption and change. In this article we briefly describe VHRD, analyze reskilling and upskilling trends during the pandemic, and address learning, cultural, workplace, and economic implications.

\section{Primer on Virtual HRD}

VHRD is no longer in the realm of theory, though the roots of it were based in research from the earliest days (Bennett \& McWhorter, 2014; McWhorter \& Bennett, 2010). Many definitional elements are plainly observed in the pandemic response. The backbone of VHRD is 
an organizational intranet or those internal systems that network various technologies, digital objects, knowledge, applications and people together; it is defined as "a media-rich and culturally relevant web[bed] environment that strategically improves expertise, performance, innovation, and community building through formal and informal learning” (Bennett, 2009, p. 365). Unlike traditional HRD, it is an environmental perspective in which many development activities occur enabled by technology.

A webbed environment in this definition means networked technology rather than synonymous with the Internet or Web. As such there can be many intranets in use of varying degrees of size and reach, including personal human intranets (Bennett, 2018). Growth of intranets for learning and development was anticipated in VHRD (Bennett, 2009). According to a Linkedin Learning (2020) survey, 56\% of learning and development professionals use an employee intranet to promote programs, and it is also the top venue for organizational members to seek out learning opportunities. Virtual HR was conceptualized as an umbrella term that included management and development from an ecological perspective that includes harmonies and constraints where these functions exist in the same system or impact one another (Bennett \& Bierema, 2010). Because the environment is virtual, it is literally unlimited and expandable into many geographically distributed places. Businesses practiced this in the pandemic with teleconferencing software-connected business professionals working from a multitude of home offices and kitchen tables.

The definition of VHRD is to an extent aspirational, recognizes the cultural and social organizational characteristics embedded in and learned through rich technologies (Bennett, 2014a, 2014b), and predicated on both formal and informal learning (Bennett, 2009). Increasingly, it is inclusive of AI and machine learning as a form of organizational learning in 
addition to human learning (Bennett \& McWhorter, 2017a). Learning is critical for performance, expertise development, innovation, and community building that are strategically aligned with professional and organizational objectives (Bennett, 2009, 2014a).

VHRD has long argued that HRD professionals need to help design technology - and we take a very broad view of what counts as technology — at the point it is envisioned, developed, implemented, as well as taught in training classes (Bennett, 2014a). HRD's role should be far earlier in the process during crisis and transformation, one that builds proper harmonies and constraints with management.

Bennett (2014a) conceptualized two modes of technology development in which HRD tools, theories, and techniques are fused with technology in a way that expands learning and performance capacity. The pandemic required significant, rapid technology development for continuity of both work and learning, which required reimagining the workplace, creating new norms, and jumpstarting skill development that position both current workers and future workers - such as students who had to adjust quickly to online learning and then will carry these skills into the future workforce - to embrace technology-mediated environments and VHRD.

\section{Reskilling and Upskilling in the Technology Era}

A new technological era was already underway in advance of Covid-19, called the fourth industrial revolution or second machine age (Brynjolfsson \& McAfee, 2014), sometimes termed the second information age. As many as half the jobs known today are going away, some due to the already extant technology revolution and others due to the pandemic fundamentally reshaping the economy and how work is done. For example, supply chains were significantly disrupted during the pandemic, which increased prices and required significant re-routing of goods and services. AI was employed to analyze many trends discernible only through 
supercomputing, including analysis of airline tickets to determine where Covid-19 might spread next (McCall, 2020), searching vast medical records for Covid-19 symptom patterns (Ozturk, et al., 2020), and how to maintain food supplies (Vanover, 2020).

Given isolation guidelines and quarantine orders, people could access health resources online, utilize telemedicine, and monitor health conditions at home with standalone or IoT connected devices (Bennett \& McWhorter, 2020). The need for social isolation required greater use of technology and with it, new skills.

\section{Analysis of Industry Reports}

To document new skills and work shifts, an Internet search was conducted to locate industry reports that reflected survey responses of business professionals (March-June 2020). Table 1 highlights six reports that were purposively chosen and analyzed (Lincoln \& Guba, 1985) due to their data collection and discussion of new work practices during the pandemic, documentation of respondents, and soft and hard skills identified. Three themes emerged from these reports and Table 1 synthesizes the COVID-19 labor reports utilizing the theme descriptions, technology facilitated processes and skills. The soft and hard skills are depicted with source numbers in parenthesis corresponding to the reports listed below the table.

[Insert Table 1 about Here]

Theme 1, On the fly: Employees' rapid shift to remote work, was descriptive of the events of early Spring 2020 when millions of workers left the workplace to work virtually from home. Technology-facilitated processes were led by video conferencing platforms (i.e. Zoom) that connected workers to co-workers/customers/clients. Skills needed during this time included soft skills such as adaptability, creativity, and empathy. For example, a PwC US survey conducted in June 2020 with 6,400 professionals (Van Buggenhout, Murat, \& Susa, 2020) reported that overall productivity of employees appeared to be skewed by a cohort of superachievers (one- 
third of total sample) that disguised a decline in productivity among the remaining two-thirds who reported working longer hours than before the pandemic. The researchers surmised fewer distractions and crisis adrenaline led to the superachievers' productivity while the other twothirds reported work from home a challenge. However, there was a rise in "collaborative activity" (p. 5) as measured by their digital performance technology system following the lockdown. Hard skills required in this period included digital literacy, customer service, and project management, among others.

Theme 2, New-normal: Working collectively together-apart, describes the late Spring through Summer (2020) when many employees who were working remotely returned to the office partially or fully. However, even while in the same workspace, regular routines changed, like wearing facemasks and social distancing measures (McKinsey \& Company, 2020a). Technology remained very important for communication outside the organization, but also for safety and learning (Go1, 2020).) A survey of 100 U.S. executives projected that their workforces would return-from-home to the workplace with $80 \%$ of employees by September 2020 and $88 \%$ by December (McKinsey \& Company, 2020a p. 2). Return-to-work initiatives were necessitated by interventions through physical changes (i.e. reducing number of employees onsite, physically separating workstations) and technology interventions (i.e. moving large meetings online, using touch-free devices instead of handles).

Theme 3, Reskilling-Upskilling: Building key skills, emphasizes the necessity of learning and development efforts to sustain worker productivity. Reskilling prepares employees for new jobs and changes, while upskilling prepares employees for advancing within their current career tracks. To this end, Fine et al., (2020) reported that the pandemic "ushers in a new paradigm for reskilling across three dimensions" (p. 7) that includes physical distancing necessitating online 
training and requires creativity to deliver training, especially soft skills like teamwork. Also, "rapid reskilling requires much shorter interventions and a different system to recognize those skills. Microcredits will replace traditional degrees in many cases" (pp. 7-8). Third, industrylevel reskilling opportunities should be collaborative and "a mindset shift toward the greater good of society" (p. 8) along with empathy as a necessary skill by "caring enough to place responsibility for long-term futures above short-term gains, and creating space for people to be their whole selves" (Mercer, 2020, p. 2) through reskilling and upskilling efforts.

Table 1 demonstrates that technical skills are needed concurrently with cognitive, creative, and intrapersonal skills, or the combination of high tech and high touch (Bennett, 2010; Swanson \& Holton, 2001). VHRD needs to be able to foster these skills by building sophisticated and compelling environments for authentic learning. Use of technology in the era of COVID-19 has accelerated digital transformation. Table 2 illustrates technology interventions garnered from labor reports cited in Table 1 plus five additional business articles published during the pandemic (Agrawal et al., 2020; Gandzeichuk \& Forbes Technology Council, 2020; Johnson, 2020; Stillman, 2020; van Hoek \& Lacity, 2020).

[Insert table 2 about here]

Pre- and post-pandemic conditions created new technologies and corresponding need for upgrading skills. These technologies will shape how the current and future workforce develop, as well as bring new consumer expectations and needs, creating new markets for goods and services. It has been oft-stated that education tends to lag behind on technology, but the pandemic created a survival crisis requiring rapid innovation by educators and learning institutions.

\section{Moving Education Online}


Globally, in efforts to promote the safety of students and educational employees during COVID-19, many colleges and universities rapidly moved all courses online and "implemented remote work for the majority of employees, and shuttered countless public spaces and programs" (Wigginton et al, 2020, p. 1190). Institutions recognized that timely adaptations for remote learning and work were essential to their viability and continued student learning (Gedro et al, 2020). However, a May 2020 survey of 1,008 undergraduate students in the U.S. revealed that the shift from face-to-face to fully online courses due to COVID-19 left them struggling to learn and stay motivated due to lack of instructor feedback and collaboration with fellow students; many had difficulties with the technology and indicated they were least satisfied with courses with few online learning strategies (Digital Promise, 2020). A scholar asked the question of ensuing radical policy changes to full online instruction, "will we ever be able to return the genie back into the bottle?" (Tesar, 2020, p. 556).

To stay relevant and engaged with students, innovative learning initiatives were enacted higher education. For example, the Faculty of Architecture's 4-day workshop at the University of Belgrade adapted to include online meetings that discussed "new, innovative typologies and architectural scenarios that will enable daily activities to be carried out safely and effectively even in time of a pandemic" (Milovanovi'c, 2020 et al., p. 4). The University of Texas at Tyler (2020) sponsored a series of webinars to connect undergraduate students with HRD scholars and afterward held an informal meetup for students to gather online following each webinar. Also, students at Tufts University (2020) were invited to weekly seminars online for staying connected as a community to help students to discern conflicting Covid-19 information/misinformation.

However, public backlash ensued as the pandemic closed childcare centers and schools beginning Spring 2020 and parents began being both worker and teacher, overloaded with 
dueling roles (Dean, 2020). Miller (2020) noted that social distancing requirements for COVID19 changed on-site employment to residences with dual role of both teacher and remote worker. In contrast, Facebook and Google employees without children claimed inequity due to increased workload and less time off than those with children at home (Wakabayashi \& Frenkel, 2020).

As work and education swiftly moved online, educators, parents, and students found they needed new skills for successfully communicating and navigating educational requirements (Buchholz, DeHart \& Moorman, 2020). Likewise, workers must acquire new literacies not previously emphasized or known.

\section{New Literacies in Education and VHRD}

Students and professionals alike, now and in the future, need a balance of hard, technical skills and soft, intrapersonal skills that can be effectively practiced both face-to-face and mediated through technology. This means that new literacies should be incorporated into education and training.

New literacies such as data literacy, digital literacy, and technology literacy must be balanced with soft skills and high touch for leadership at all levels, organizational development, strong performance adaptation and for building VHRD (Bennett, 2014a; Bennett \& Gorman, 2018). Data literacy is knowing "where to acquire data, how to analyze it, and how to gain actionable results" (Rasheed, 2020, para. 1). For example, in 2020 the public and organizations began reading clinical studies to understand how to protect themselves from Covid-19. A good example of how people can interpret data differently is whether reusable cloth masks work, do not work, or whether they are harmful by increasing infection risk. There are many opinions on this matter alone. Data is both necessary for action and as a resource for learning. There will be an increased need of statistics and probabilistic reasoning. 
Digital literacy has been described as "finding and consuming digital content; creating digital content; and communicating or sharing it" (Heiten, 2016, para. 5). Digital skills can be taught at many learning levels, supportive of innovation. Similarly, technology literacy is "the ability to effectively use technology to access, evaluate, integrate, create and communicate information" (Estes, 2017, p. 103). Thus, we see learning and development concurrent with these literacies, supporting the view that people learn informally and develop through technological environments. These literacies support skills needed in the pandemic, but also beyond as the world recovers from economic recession and adapts to the industrial revolution underway.

\section{Pandemic VHRD: Implications and Preparing for Future Disruptions}

Reviewing how the pandemic unfolded in retrospect, it becomes clear that some things are not going back to 2019 conditions. The oft-repeated phrase new normal indicates that many have recognized this truth, even if they do not fully accept current conditions as normal or good. There has not been adequate time to mourn such a catastrophic launch into a new era; but we know enough at this stage to consider initial implications for the field that address VHRD during the pandemic but also move us beyond. There is no doubt that the world is currently in crisis with financial, health, and civil consequences that will all affect HRD practice and research.

\section{Learning Agility and Resilience}

HRD as a field champions learning as a critical part of performance and organization development, with both formal and informal learning fundamental processes in VHRD (Bennett, 2009). While past economic crises saw training and development departments slashed to save cost, and this could be the case at present, we anticipate the value of learning and development assets will be recognized and protected like no other time in history. These assets create strategic advantage for corporations to not only recover with resilience but to leverage planning to thrive 
in the technology-enabled future. This expectation is supported by recent industry reports reviewed (i.e. Mercer, 2020).

The era of high technology and AI will not be uniform; in some cases, humans will still do routine jobs where the cost of developing AI is too high. Some things simply do not make sense to automate. However, more automation is showing up in everyday activities, such as how lunch is served at a fast food restaurant. Robots and machines help reduce contact and maintain social distance, and they simultaneously collect data for analysis. Given how many jobs will be lost to automation, people need to be agile in their learning and provide value that machines cannot yet provide. The purpose of high technology is not to automate per se, but to augment work. Rapid advancement of technology and the large volume of data generated requires learning agility and resilience to bounce back from setbacks and changes. As new analysis unfolds, humans will need to learn quickly how to respond when a new direction is indicated.

Learning agility is both an orientation toward learning (willingness) and the capability to use experience as a source for learning and to navigate new conditions for successful outcomes (Eichinger \& Lombardo, 2004). We add that learning agility should include the ability to switch learning modes adeptly and to use intuition, metacognition, and creativity to adapt to new conditions, solve problems, as well as further develop learning capacity and learning how to learn. An interesting aspect of learning agility is that it is not easy to predict what needs to be learned in advance and so people need to be learning-ready. For example, the difference between leaders who succeed and those who fail has to do with taking responsibility for adjusting to a wide variety of situational characteristics, rather than being inflexible in style or blaming others for missteps (De Meuse, Dai, \& Hallenbeck, 2010).

Learning agility needs a creative approach, too. Creativity requires incubation time for 
unconscious processing (Bennett, 2012; Starko, 2001) and solitude (Kaufman \& Gregoire, 2015), which are often in short supply during crisis. This is especially important given overemphasis on collaboration and check-in meetings that interrupt focus-time. Given the current and future changes, we recommend organizations do not wait to begin the process of enhancing the skills given the revolution of work. Some questions HRD professionals should consider:

1. What capacity does your organization have for learning? How can capacity be increased?

2. How is learning recognized and rewarded? Both formal and informal learning?

3. How are learning errors addressed? Are learners punished for taking risks?

4. How has your organization surveyed the current state of talent, including new skills adopted during the pandemic?

5. How does your intranet and technology strategy support learning? What environment do these create?

6. What gaps in skills and knowledge acquired during the pandemic should be closed?

7. What new skills are needed to for your organization to be resilient and thrive beyond the pandemic?

There is an opportunity to leverage learning by circling back with employees and further developing skills that were learned in crisis-mode. HRD professionals and organizational members must be learning leaders, not just organization or function leaders. Executives play a key role in building a culture of learning, yet $79 \%$ of worldwide CEOs indicate essential skills for growth are missing (Linkedin Learning, 2020), which means it is in their interest to support 
and invest in learning.

\section{Alternative Workplace Strategies, Changing Business Norms, and Wellbeing}

VHRD literature has discussed alternative work strategies, including what has been known by the archaic term telecommuting and other forms of virtual work, as well as wellbeing, critical HRD, trust in teams and manager-employee relationships, and ethics where employees may be out of sight for promotion or online too long for proper work-life balance (Bennett, 2009; Bennett \& Bierema, 2010; Thomas, 2014). Given that creativity needs solitude, being too accessible through technology is detrimental at times. The pandemic pushed more people to work from home, and likely many jobs will remain all or partly remote throughout the pandemic and beyond. Organizations may rightly question whether to continue to invest in costly physical infrastructure if work can be done as well, or better, offsite. Employees, and the environment, may benefit from reduced commuting; however, this requires new norms for work that support high performance and wellbeing.

As the pandemic hit, business norms began changing. A good example of a first norm to change was the classic handshake. As governments began responding and locking down, the world revisited definitions of essential and non-essential workers, the latter able to either work offsite or furloughed if not. Those who were able to continue working virtually were privileged to have jobs, whereas racial disparity arose to public consciousness due to who tends to occupy essential positions, like delivery services and groceries, and who was most at risk for worse outcomes due to Covid-19's mode of attack (See: Chowkwanyun, et al., 2020; McLaren, 2020). These are important areas to consider for equity and for re-opening plans. We project that some positions will remain virtual, especially in states like California that are beginning to view work from home as a right. This will further blur the line between employees and independent 
contractors and raise questions about who outfits and pays for home offices, as well as how to support learning and development from a distance. In other words, how to develop people through VHRD and how to recognize the innate development of people working in technologyenabled systems with lots of data.

There is no doubt Covid-19 had substantial impact on physical wellbeing and emotional burden of workers. Concern for health of loved ones, adopting new hygiene standards, lay-off anxiety, and learning to work in new ways created emotional labor that the field has not yet studied or understood. As more business meetings went online from home, many organizations turned to teleconferencing programs. New terms like Zoom fatigue and Zoom bombing (Daigle, 2020) demonstrate stressors as well as new regard for cybersecurity. New norms were created to address how to work virtually, especially given some managers lack skill in this area and may use outdated and heavy-handed methods for virtual teams (Bennett \& Bierema, 2010).

As millions of people began to work from home, some with little remote work experience, concerns for security drove global virtual private network (VPN) usage up by 35\% (Cadir, 2020). While some may have been concerned about loafing, VPN data analyzed during the early days of the pandemic also indicated workers were putting an extra three hours on the job per day in some areas, causing deep concern for work-life balance (Davis \& Green, 2020). Organizations are at risk of losing talent when this toll is unrecognized. Alternatively, the increased load virtual jobs with dependent schooling for families has created a gender gap in

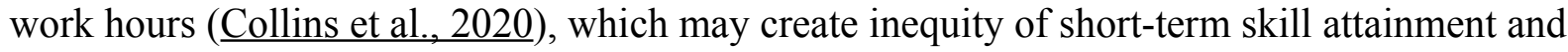
longer-term career development. It also indicates these women may be hit harder in this current crisis than in past downturns.

Re-centering life to the home - streaming entertainment, work, and school - is shifting 
society in ways not yet understood. How organizations manage during this time will affect the organization's culture as new policies, values, and modes of work become embedded in organizational history.

\section{Cultural Work, Trust, and Technology Development}

VHRD is social and cultural work, and a sense of belonging is a deep human need that is just as strong when virtual. Cultural relevancy has been embedded in the definition of VHRD since 2009, primarily focused on organizational culture, though personal, national, and discipline culture are also evident (Bennett, 2009, 2014b). Prior research has shown that culture can be learned through a corporate intranet or VHRD (Bennett, 2014b). Edgar Schein's perspective of organizational culture is that it results from shared learning, and culture change is difficult to accomplish even when the data supports need for change, requiring survival anxiety to be higher than learning anxiety (Schein \& Schein, 2017). Rapid technology development during Covid-19 indicates that survival anxiety did indeed override learning anxiety. Teachers, for example, had to place a significant amount of content online and learn new technologies at an unheard-of pace given sudden pandemic closures. Many of the typical cultural rites of passage and rituals were either skipped or altered to accommodate social distancing, such as graduation ceremonies and retirements. Businesses realized that they needed to adapt or die, and cottage industries sprang up, such as homemade masks on direct market sites like Etsy.com.

Social bonding is critical for organizations to function well, and telecommuting isolation required novel ways of connecting teams and leaders. Prior VHRD literature discusses trust and virtual team management (Bennett \& Bierema, 2010), including the very real threat of overmanagement (Foster, 2020). In fact, pandemic news stories described managers not used to working in virtual environments demanding their employees turn on cameras regularly 
throughout the day and using monitoring software (Evans, 2020; Satariano, 2020). This type of managing by distrust causes toxic culture and employee disengagement. It is far better for managers to develop good key performance indicators and have regular, but not excessive, check-ins based on an ethic of care and trust in employees. Consider what fosters belonging and engagement through technology and build that instead.

HRD professionals and leaders need to shape reasonable policies that support employees and managers even in crisis technology development. The need for policy and sector seals of approval for technologies that capture private data has been discussed in VHRD, particularly for competing intranets that combine people, things, and services in a seamless system (Bennett, 2018). This is especially the case as technology becomes increasingly invasive and even 'creepy' (McWhorter \& Bennett, 2020). Covid-19 demanded many HRD practitioners engage in rapid technology development that is isomorphic with culture (Bennett, 2009, 2014b; Bennett \& McWhorter, 2017b). Virtual recruitment and onboarding, for example, became necessary features of pandemic VHRD to keep the economy and business continuity moving.

\section{Economics and Recovery}

Swanson and Holton (2001) described how economic theory has been an important support in HRD's three-legged stool, along with systems theory and psychology. Economics studies the distribution of scarce resources, whether the limited resource is data, time, money, products, software, customers, skills, and the like. Significant supply chain disruption occurred during the pandemic, which underscores the need for learning and analytics to anticipate and respond to changing economic conditions, which can be helped or hampered by technology. Of supply chain managers surveyed in one study, $82 \%$ were frustrated by a) AI software due to lack of reliable data, b) diminished data-driven decision-making capacity of organizational leaders 
who lacked knowledge on the ground, c) inability for AI to function well in unprecedented situations, and having to return to manual analysis, demonstrating the need for better human-AI collaboration (Briggs, 2020). AI is part of the VHRD environment, particularly with learning analytics; however, human talent and insight is still an important scarce resource to protect.

Economic effects were widely felt in the pandemic. The shift of work and school to home was a significant part of shortages since products that were created for institutional purchasers, like cafeteria food and paper goods, could not easily or inexpensively be retrofitted for retail customers. While some may have blamed panic buying for the infamous toilet paper shortage of 2020 in the United States, there were industrial sized wheels of paper available, the wrong supply suddenly altered conditions.

Stores and producers struggled to keep product in stock, especially as vulnerable workers called out or became sick. Hazard pay was a way to incentivize employees for working in-person despite Covid-19 risks. Rapid re-routing of goods and services occurred, a function of free markets and a critical part of recovery and virtual integration. The downside is that some areas of the world were outbid for products because customers in developed countries could pay. Price signals also helped keep shortages at bay since people tend to buy less when costs rise, leading to conservation behavior as well. The anxiety of shortages affected consumers and likely added new emotional labor for employees. Some behaviors stemming from pandemic economics, and resulting anxieties, may need to be unlearned.

There seems to be a growing shift from urban to suburban centers that questions the future of megacities that produce a vast majority of country GDP, calling for the need to reimagine the post-pandemic economy that involves inclusive growth and innovation investment (McKinsey \& Company, 2020b). Prevailing wisdom suggests it is important to diversify and 
explore new ecologies of activity that can insulate communities from future economic shock. The pandemic also points to the need for countries to re-shore manufacturing in the interests of national security, such as personal protective equipment and pharmaceuticals. On the one hand, life has been re-centered on the home, and on the other hand, decentralized from large, populous hub. No matter how one looks at the situation, technology played a major role, and will continue to do so. In fact, digital currency may be a next evolution (see blockchain in Table 1). These economic issues and trends have had profound impact on employees and organizations as well as the process of recovery. HRD professionals, and graduate programs that help prepare them, should teach economic theory as well as techniques that help anticipate and respond to future disruptions.

\section{Preparing for Future Disruptions with Scenario Planning}

How can organizations plan for future catastrophic events? In 1960, Herman Kahn alerted leaders about the potential of thermonuclear war as an effort to help them grasp the grim possibilities of such an event and develop strategies beforehand to thwart its occurrence. Various methods for strategic planning have been offered to predict and manage events of global proportions including "futuring" (Hoyle, 2007, p. 1) activities to prepare organizations for the forthcoming environment. These planning activities include long-term strategic planning and scenario planning (SP).

One method for long-term strategic planning was offered by Webb (2019) who uses a concept of "time cones, not time lines" (para. 11) with a team that draws a cone with four categories (tactics, strategy, vision, and systems-level evolution) and identifies highly probable events supported by existing evidence or data. Then, the planning team moves outward from the tip of the cone to increased time and less certainty due to less data and evidence. As more data 
and evidence are collected verifying progress on actions, "the beginning of the cone and your tactical category is always reset in the present day. The result, ideally, is a flexible organization that is positioned to continually iterate and respond to external developments" (para. 18). In other words, it supports learning agility and a culture of learning.

Scenario planning has been posited for catastrophic event preparation. Chermack (2011) presented scenario planning as "a tool for helping decision makers reperceive the potential future in alternative ways. Having these alternative ways of seeing helps decision makers avoid surprises and prepare for a variety of plausible futures" (p. 3). A recent article published in March 2020 reported on a scenario planning (SP) activity (held before the pandemic) involving twenty experts representing areas of national security, emergency response, biosciences, and global health. Their SP session was designed specifically "to stress-test U.S. approaches to global health challenges that could affect national security" (Brannen \& Hicks, 2020, para. 2). The article reflected the accuracy of the behavior of a coronavirus in their scenario that "spread much as today's virus does, jumping between countries via international air travel, causing problems not only for health systems, but for economies and political leaders" (para. 8) thus demonstrating that SP is advantageous for preparing organizations for future negative and even catastrophic events.

McWhorter and Lynham (2014) theorized virtual scenario planning (VSP) as a costeffective learning tool that utilizes virtual technologies for crafting strategy in real-time with disbursed stakeholders, thus improving decision-making and participants' abilities to respond to changes in the environment. VSP can also help shift perceptions more quickly as unexpected events unfold and could be carried out with current video conferencing platforms such as Zoom, Skype, or Microsoft Teams. Scenario planning, like other techniques in the field, intersects with 
VHRD to capture knowledge, strategies, and increase learning and cultural readiness to meet future crises.

\section{Conclusion}

Crisis will come around again, and digital transformation due to the fourth industrial revolution is afoot. We mark 2020 as the year millions of people joined the world of VHRD, with some sobering and inspiring clues to what lies ahead in the fourth industrial revolution. We renew the call for HRD programs to incorporate technology beyond instructional software and online training, such as interdisciplinary consulting projects (Bennett, 2010), as well as greater emphasis on data analytics with emphasis on high touch and human need to belong. HRD professionals must embrace their growing roles in technology development and designing virtual learning environments. VHRD is necessary to help organizations recover from Covid-19 and to thrive in a world increasingly powered by AI, robotics, and a multitude of unseen intranets. In closing this article, we would like to thank those on the front lines, in healthcare, essential workers, organizations who ensured less disruption within supply chains, governments, and the many who bore up under great pressure to maintain business continuity at a time of great threat and loss. 


\section{References}

Agrawal, S., De Smet, A., Lacroix, S., \& Reich, A. (2020). To emerge stronger from the COVID-19 crisis, companies should start reskilling their workforces now. https://www.mckinsey.com/business-functions/organization/our-insights/to-emergestronger-from-the-covid-19-crisis-companies-should-start-reskilling-their-workforcesnow

Bennett, E. E. (2009). Virtual HRD: The intersection of knowledge management, culture, and intranets. Advances in Developing Human Resources, 11, 362-374.

Bennett, E. E. (2010). The coming paradigm shift: Synthesis and future directions in virtual HRD. Advances in Developing Human Resources, 12(6), 728-741.

Bennett, E. E. (2012, June). A four-part model of informal learning: Extending Schugurensky's conceptual model. In J. Buban \& D. Ramdeholl (Eds.), Proceedings of the 53 Adult Education Research Conference May 31-June 3, 2012 (pp. 24-31). Saratoga Springs, NY: SUNY Empire State College.

Bennett, E. E. (2014a). Introducing new perspectives on virtual human resource development. Advances in Developing Human Resources, 16(3), 263-280.

Bennett, E. E. (2014b). How an intranet provides opportunities for learning organizational culture: Implications for virtual HRD. Advances in Developing Human Resources, 16(3), 296-319.

Bennett, E. E. (2018). Intranets of people, things, and services: Exploring the role of virtual human resource development. In C. A. Simmers \& M. Anandarajan (Eds.). The Internet of People, Things and Services (pp. 166-183). Routledge.

Bennett, E. E., \& Bierema, L. L. (2010). The ecology of virtual human resource development. Advances in Developing Human Resources, 12(6), 632-647. 
Bennett, E. E., \& Gorman, M. (2018). Informal and experiential learning in virtually mediated organizational doctoral studies. In L. Hyatt \& S. Allen (Eds.). Advancing Doctoral Leadership Education through Technology (pp. 97-107). Edward Elgar.

Bennett, E. E., \& McWhorter, R. R. (2014). Virtual human resource development. In N. E. Chalofsky, T. F. Rocco, \& M. L. Morris (Eds.), Handbook of Human Resource Development (pp. 567-589). Wiley.

Bennett, E. E., \& McWhorter, R. R. (2017a), Organizational Learning, Community, and Virtual HRD: Advancing the Discussion. New Horizons in Adult Education and Human Resource Development, 29, 19-27. doi:10.1002/nha3.20188

Bennett, E. E., \& McWhorter, R. R. (2017b). International HRD and Virtual HRD. In T. Garavan, A. McCarthy, \& R. Carbery (Eds.). A handbook of International HRD: Context, processes and people. Edward Elgar publishing.

Bennett, E. E., \& McWhorter, R. R. (2020). Digital technologies for teaching and learning. In T. Rocco, M. C. Smith, R. C. Mizzi, L. R., Meriweather, \& J. D. Hawley (eds), 2020 Handbook on Adult and Continuing Education (pp. 177-186). Stylus.

Brannen, S., \& Hicks, K. (2020). We predicted a coronavirus pandemic. Here's what policymakers could have seen coming. https://www.politico.com/news/magazine/2020/03/07/coronavirus-epidemic-predictionpolicy-advice-121172

Briggs, F. (2020, June). 82\% of supply chain managers using AI systems for decision-making left frustrated during COVID-19 pandemic, study finds. https://www.retailtimes.co.uk/82-of-supply-chain-managers-using-ai-systems-for- 
decision-making-left-frustrated-during-covid-19-pandemic-study-finds/

Brynjolfsson, E., \& McAfee, A. (2014). The second machine age: Work, progress, and prosperity in a time of brilliant technologies. Norton.

Buchholz, B. A., DeHart, J., \& Moorman, G. (2020). Digital citizenship during a global pandemic: Moving beyond digital literacy. https://ila.onlinelibrary.wiley.com/doi/pdf/10.1002/jaal.1076

Cadir, B. (2020, June 15). Global VPN use increased by 35\% during pandemic. [news article] https://www.kivodaily.com/technology/global-vpn-use-increased-by-35-duringpandemic/

Chermack, T. (2011). Scenario planning in organizations. Berrett-Koehler.

Chowkwanyun, M., Reed, A. L., \& Reed, A. L. (2020). Perspective: Racial health disparities and Covid-19: Caution and context. https://www.nejm.org/doi/full/10.1056/NEJMp2012910

Collins, C., Landivar, L. C., Ruppanner, L., \& Scarborough, W. J. (2020). Covid-19 and the gender gap in work hours. Gender Work Organization, 2020, 1-12.

Doi:10.1111/gwao.12506

Cutler, D. M., \& Summers, L. H. (2020, October 12). The Covid-19 pandemic the $\$ 16$ trillion virus. Viewpoint. JAMA. Doi:10.1001./jama.2020.19759

Daigle, T. (2020, May 27). Zoom fatigue is setting in: What it is and how to prevent it. https://www.cbc.ca/news/technology/zoom-fatigue-is-setting-in-1.5585933

Davis, M. F., \& Green, J. (2020, April 23). Three hours longer, the pandemic workday has obliterated work-life balance [news article]. Bloomberg. https://www.bloomberg.com/news/articles/2020-04-23/working-from-home-in-covid-erameans-three-more-hours-on-the-job 
Dean, S. (March 31, 2020). Google, Facebook offer paid leave to parents amid coronavirus school closures. https://www.latimes.com/business/technology/story/2020-03-

\section{$\underline{\text { 31/coronavirus-google-facebook-paid-leave-school-closures }}$}

De Meuse, K. P., Dai, G., \& Hallenbeck, G. S. (2010). Learning agility: A construct whose time has come. American Psychological Association, 62(2), 119-130.

Digital Promise (2020). Suddenly Online: A national survey of undergraduates during the COVID-19 pandemic.

https://digitalpromise.dspacedirect.org/bitstream/handle/20.500.12265/98/DPSuddenlyOn lineReportJuly2020.pdf? sequence $=3$

Eichinger, R. W., \& Lombardo, M. M. (2004). Learning agility as a prime indicator of potential. Human Resource Planning, 27, 12-16.

Estes, J. S. (2017). Teacher preparation and learner-centered, technology-integrated instruction. (pp. 85-103). In Handbook of Research on Learner-Centered Pedagogy in Teacher Education and Professional Development. J. Keengwe \& G. Onchwari, eds. IGI Global.

Evans, E. (2020, July 27). This tech could let bosses spy on you while you're working from home. https://www.deseret.com/indepth/2020/7/27/21326471/coronavirus-working-fromhome-remote-employee-surveillance-software-time-doctor-prodoscore

Fine, D., Klier, J., Marajan, D., Raabe, N. Schubert, J., Singh, N., \& Ungur, S. (2020). How to build and reimagine jobs amid the coronavirus crisis. https://www.mckinsey.com/industries/public-and-social-sector/our-insights/how-to$\underline{\text { rebuild-and-reimagine-jobs-amid-the-coronavirus-crisis }}$ 
Foster, W. (2020). How to hold remote workers accountable without micromanaging: Good managers don't actually care what folks do with their time. They care if the job gets done. Inc. https://www.inc.com/wade-foster/how-to-hold-remote-workers-accountable-withoutmicromanaging.html

Gandzeichuk, I., \& Forbes Technology Council (2020). What tech trends will continue to grow post-pandemic? https:/www.forbes.com/sites/forbestechcouncil/2020/05/12/what-techtrends-will-continue-to-grow-post-pandemic/\#18dc87982460

Gedro, J., Allain, N. M., De-Souza, D., Dodson, L., \& Mawn, M. V. (2020). Flattening the learning curve of leadership development: Reflections of five women higher education leaders during the Coronavirus pandemic of 2020. Human Resource International, 23(4), 395-405. https://doi.org/10.1080/13678868.2020.1779911

Go1 (2020). State of learning report: Learning at Work in 2020. https://www.go1.com/en$\underline{\mathrm{au} / \text { resource/in-light-of-the-unprecedented-events-of-2020-so-far }}$

Heiten, L. (2016). Digital literacy: An evolving definition. https://www.edweek.org/ew/articles/2016/11/09/what-is-digital-literacy.html

Hoyle, J. R. (2007). Leadership and futuring: Making visions happen. Corwin Press.

Istrate, E., \& Harris, J. (2017). The future of work: The rise of the Gig Economy. https://www.naco.org/featured-resources/future-work-rise-gig-economy

Johnson, A. (2020). How to prepare your workplace and workforce for the 'New Normal' in the post-COVID-19 Era. https://harver.com/blog/workplace-and-workforce-in-the-postcovid-19-era/

Kaufman, S. B., \& Gregoire, C. (2015). Wired to create: Unraveling the mysteries of the creative mind. Perigee. 
Lincoln, Y. S., \& Guba, E. G. (1985). Naturalistic Inquiry. Sage.

Linkedin Learning (2020). 2020 Workplace learning report. Linkedin. https://learning.linkedin.com/resources/workplace-learning-report

McCall, B. (2020). COVID-19 and artificial intelligence: protecting health-care workers and curbing the spread. https://www.thelancet.com/action/showPdf?pii=S2589$\underline{7500 \% 2820 \% 2930054-6}$

McKinsey \& Company (2020a). How US companies are planning for a safe return to the workplace. https://www.mckinsey.com/industries/pharmaceuticals-and-medicalproducts/our-insights/how-us-companies-are-planning-for-a-safe-return-to-the-workplace

McKinsey \& Company (2020b). Reimagining the postpandemic economic future. https://www.mckinsey.com/industries/public-and-social-sector/our-insights/reimaginingthe-postpandemic-economic-future

McLaren, J. (2020). Racial disparity in COVID-19 deaths: Seeking economic roots with census data. http://www.people.virginia.edu/ jem6x/mclaren $\% 202020 \% 20 \mathrm{racial} \% 20$ disparity \%20in\%20covid-19.pdf

McWhorter, R. R, \& Bennett, E. E. (2010). Virtual human resource development. Advances in Developing Human Resources, 12(6), 619-641.

McWhorter, R. R., \& Bennett, E. E. (2020). Creepy technologies and the privacy issues of invasive technologies. In Disruptive and Emerging Technology Trends across Education and the Workplace, J. A. Delello \& R. R. McWhorter, Eds. (pp. 243-268). IGI Global. McWhorter, R. R., \& Lynham, S. A. (2014). An initial conceptualization of virtual scenario 
planning. Advances in Developing Human Resources, 16(3), 335-355.

Mercer (2020). Win with empathy: Global talent trends 2020.

https://www.mercer.com/content/dam/mercer/attachments/global/gl-2020-talent-trendsinfographic-industry-life-sciences.pdf

Miller, C. C. (2020). Three things lockdowns have exposed about working and parenting. The New York Times. https://www.nytimes.com/2020/04/27/upshot/coronavirus-exposesworkplace-truths.html

Milovanovi'c, A., Zoric, A., Djordjevic, A., \& Kostic, M. (2020). Transferring Covid-19 challenges into learning potentials: Online workshops in architectural education. Sustainability, 12(7), 7024.

Ozturk, T., Talo, M., Yildirim, E. A., Baloglu, U. B., Yildirim, O., \& Acharya, U. R. (2020). Automated detection of COVID-19 cases using deep neural networks with X-ray images. Computers in Biology and Medicine. 2020;121:103792. doi:

10.1016/j.compbiomed.2020.103792.

Rasheed, R. (2020). How data literacy can make you a better professional in 2020. https://towardsdatascience.com/how-data-literacy-can-make-you-a-better-professional-in$\underline{2020-e 13 c 7 a d d d 208}$

Satariano, A. (2020, May 6). How my boss monitors me while I work from home. https://www.nytimes.com/2020/05/06/technology/employee-monitoring-work-from$\underline{\text { home-virus.html }}$

Schein, E. H., \& Schein, P. (2017). Organizational culture and leadership (5 $5^{\text {th }}$ Ed.). Wiley. 
Starko, A. J. (2001). Creativity in the classroom: Schools of curious delight ( $2^{\text {nd }}$ ed.). Lawrence Earlbaum Associates.

St. John (2020). The rise of e-learning. https://www.chieflearningofficer.com/2020/07/17/the$\underline{\text { rise-of-e-learning/ }}$

Stillman, J. (2020). 10 ideas to keep a great company culture while working remotely. https://www.inc.com/jessica-stillman/10-ideas-to-keep-a-great-company-culture-whileworking-remotely.html

Swanson, R. A., \& Holton, E. F. III (2001). Foundations of human resource development. Berrett-Koehler.

Tesar, M. (2020). Towards a post-Covid-19 'New Normality?': Social Distancing, the move to online \& higher education. Policy Futures in Education, 18(4) 556-559. http://dx.doi.org/10.1177/1478210320935671

The University of Texas at Tyler (2020). Provost's annual report. https://www.uttyler.edu/academicaffairs/files/2020 annual report.pdf

Thomas, K. (2014). Workplace technology and the creation of boundaries: The role of VHRD in a 24/7 work environment. Advances in Developing Human Resources, 16(3), 281-295.

Tufts University (2020). Tisch College launches webinar for students on navigating the pandemic. https://now.tufts.edu/articles/tisch-college-launches-webinar-studentsnavigating-pandemic 
Van Buggenhout, N., Murat, S., \& de Sousa, T. (2020). Sustaining productivity in a virtual world. https://www.strategy-business.com/article/Sustaining-productivity-in-a-virtualworld?gko=f2d1a

van Hoek, R., \& Lacity, M. (2020). How the pandemic is pushing blockchain forward. Harvard Business Review. https://hbr.org/2020/04/how-the-pandemic-is-pushing-blockchainforward

Vanover, J. (2020). The ever-expanding role of AI \& AR in food logistics. https://www.foodlogistics.com/technology/article/21117608/the-everexpanding-role-of$\underline{\text { ai-ar-in-food-logistics }}$

Wakabayshi, D., \& Frenkel, S. (2020). Parents got more time off. Then the backlash started. New York Times. https://www.nytimes.com/2020/09/05/technology/parents-time-offbacklash.html

Webb, A. (2019). How to do strategic planning like a futurist. https://hbr.org/2019/07/how-to-do$\underline{\text { strategic-planning-like-a-futurist }}$

Wigginton, N. S., Cunningham, R. M., Katz, R. H., Lidstrom, M. E., Moler, K. A., Wirtz, D., \& Zuber, M. T. (2020). Moving academic research forward during COVID-19. https://science.sciencemag.org/content/sci/368/6496/1190.full.pdf

Table 1: Synthesis of Six COVID-19 Labor Reports

\begin{tabular}{|c|c|c|c|}
\hline Theme & Description & $\begin{array}{c}\text { Technology-Facilitated } \\
\text { Processes }\end{array}$ & $\begin{array}{c}\text { Soft \& Hard Skills } \\
\text { by Alpha Order }\end{array}$ \\
\hline $\begin{array}{l}\text { Theme 1: } \\
\text { On the fly: } \\
\text { Employees' } \\
\text { rapid shift to } \\
\text { remote work }\end{array}$ & $\begin{array}{l}\text { With little warning, } \\
\text { COVI9-19 forced } \\
\text { millions of employees } \\
\text { to work virtually } \\
\text {. }\end{array}$ & $\begin{array}{l}\text { Video conferencing } \\
\text { platforms for working from } \\
\text { home (WFH; } 1,2,3,4,5) \text {. } \\
\text { Team performance software }\end{array}$ & $\begin{array}{ll} & \text { Adaptability/ } \\
\text { Agility/ } & \text { Mindshifting }(1,2,3,5) \\
- & \text { Creativity }(1) \\
\text { - } & \text { Digital Leadership }(1,3) \\
\text { - } & \text { Empathy }(3,5) \\
\text { - } & \text { Innovative }(1,2)\end{array}$ \\
\hline
\end{tabular}




\begin{tabular}{|c|c|c|c|}
\hline & & & 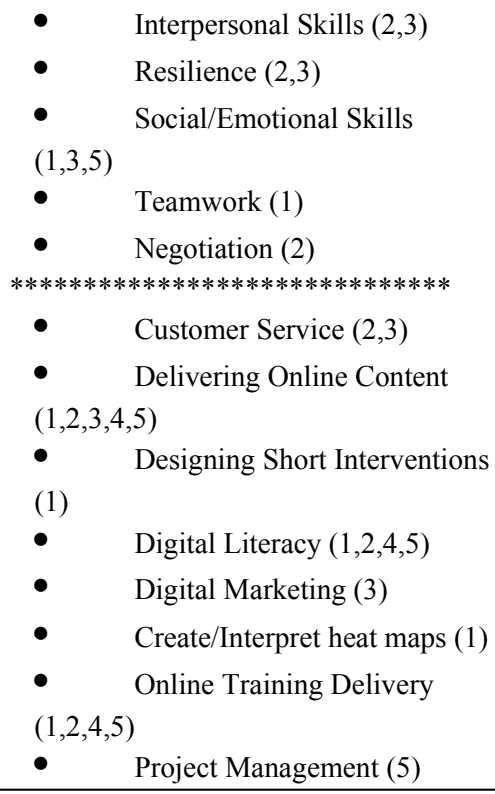 \\
\hline $\begin{array}{l}\text { Theme 2: } \\
\text { New-Normal: } \\
\text { Working } \\
\text { collectively } \\
\text { together-apart }\end{array}$ & $\begin{array}{l}\text { Social distancing } \\
\text { mandates shifted } \\
\text { traditional business } \\
\text { processes requiring } \\
\text { digital technologies for } \\
\text { safety while in the } \\
\text { office and for optional } \\
\text { remote work }\end{array}$ & $\begin{array}{l}\text { Video conferencing } \\
\text { platforms for team meetings, } \\
\text { customer service } \\
\text { Social Distancing and } \\
\text { Contact Tracing apps and } \\
\text { wearables }\end{array}$ & 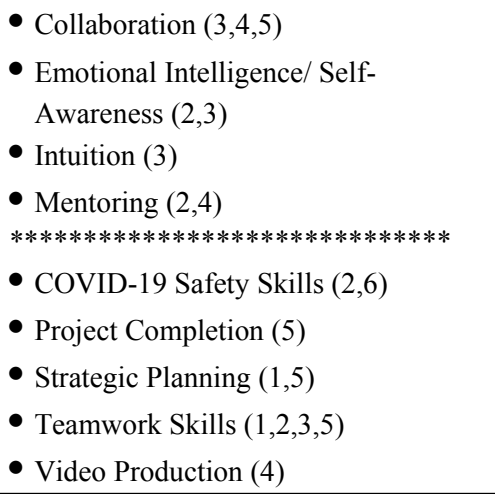 \\
\hline $\begin{array}{l}\text { Theme 3: } \\
\text { Reskilling and } \\
\text { Upskilling: } \\
\text { Building key } \\
\text { skills }\end{array}$ & $\begin{array}{l}\text { Need for employee } \\
\text { learning and } \\
\text { development to build } \\
\text { and sustain productivity }\end{array}$ & $\begin{array}{l}\text { Video conferencing } \\
\text { platforms for individual and } \\
\text { team training } \\
\text { Customized Training } \\
\text { Software }\end{array}$ & 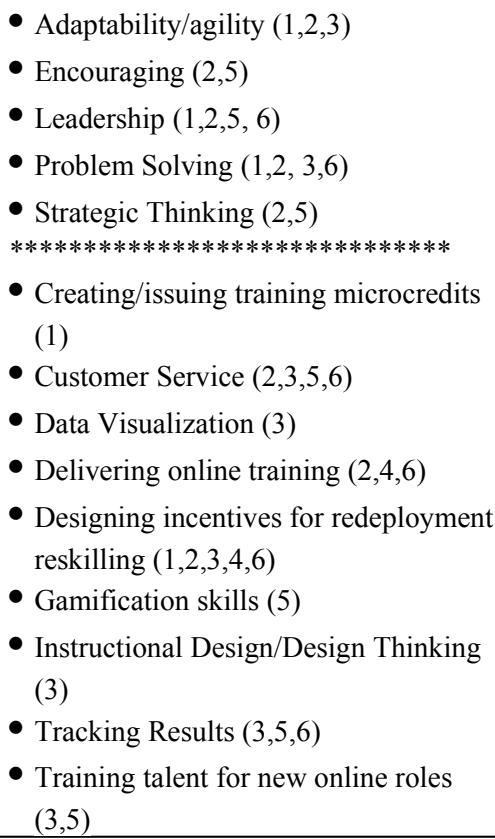 \\
\hline
\end{tabular}

1. Fine et al ( $2020 ; \mathrm{N}=1,004$ business leaders, $3 / 26 / 20-4 / 20 / 20) ; 2$. Go1 ( $2020 ; \mathrm{N}=800+$ business professionals);

3. Mercer (2020; 6,400 professionals); 4. St. John (2020; 978 CLOs);

5. Van Buggenhout et al. (2020, 129 executives \& 1,200 U.S. office workers, 5/29/20-6/4/20); 
6. McKinsey (2020a; 100 U.S. executives, 5/8/20-5/13/20)

(Total Participants $=10,600+$ )

Table 2 - Digital Technologies for the COVID-era

\begin{tabular}{|c|c|c|}
\hline $\begin{array}{l}\text { New Technology } \\
\text { Examples }\end{array}$ & Description/Authors & Examples/Uses \\
\hline \multirow[t]{2}{*}{$\begin{array}{l}\text { Social Distancing } \\
\text { Technologies }\end{array}$} & $\begin{array}{l}\text { - Video conferencing platforms used in } \\
\text { lieu of face-to-face meeting (Agrawal et } \\
\text { al., 2020) }\end{array}$ & $\begin{array}{l}\text { - Online Department Meeting } \\
\text { - Online Meeting with Customers } \\
\text { - Virtual Training Meetings } \\
\text { - Telehealth in lieu of in-person visit with } \\
\text { healthcare professional } \\
\end{array}$ \\
\hline & $\begin{array}{l}\text { - Sensors to monitor employee location } \\
\text { and movements (Gandzeichuk \& Forbes } \\
\text { Technology Council, 2020); some also } \\
\text { save contact tracing data (Johnson, 2020) }\end{array}$ & $\begin{array}{l}\text { - IoT wearable devices with proximity alert } \\
\text { of others such as Halo } \\
\text { https://www.proxxi.co/contact }\end{array}$ \\
\hline Short-form Training Online & $\begin{array}{l}\text { - } 15 \text {-minute-or-less online training module } \\
\text { in short-form to engage learners (Go1, } \\
\text { 2020) }\end{array}$ & $\begin{array}{l}\text { - Bite-sized training content with short } \\
\text { reading, use of brief audio/reading/video } \\
\text { clips }\end{array}$ \\
\hline $\begin{array}{l}\text { Customized Online Talent } \\
\text { Exchanges }\end{array}$ & $\begin{array}{l}\text { - Industry associations, and labor } \\
\text { organizations can quickly create portals } \\
\text { for employers to post openings (Fine et } \\
\text { al., 2020) }\end{array}$ & $\begin{array}{l}\text { - Displaced workers or the unemployed can } \\
\text { locate employment opportunities online }\end{array}$ \\
\hline $\begin{array}{l}\text { Data Visualization } \\
\text { Software }\end{array}$ & $\begin{array}{l}\text { - Heatmaps use color to visualize } \\
\text { data for making decisions (Fine et al., } \\
\text { 2020; Mercer, 2020) }\end{array}$ & $\begin{array}{l}\text { - Heatmaps used for visualizing } \\
\text { locales where venerable jobs could be lost, } \\
\text { requiring interventions }\end{array}$ \\
\hline E-Learning Delivery & $\begin{array}{l}\text { - } \quad \text { E-learning is course } \\
\text { materials/modules or learning event } \\
\text { delivered electronically (St. John, 2020) }\end{array}$ & $\begin{array}{l}\text { - Several short modules delivered } \\
\text { online for onboarding a new employee }\end{array}$ \\
\hline $\begin{array}{l}\text { Promoting Company } \\
\text { Culture from a Distance }\end{array}$ & $\begin{array}{l}\text { - New employees need } \\
\text { reinforcement of the company culture, } \\
\text { especially when working from home } \\
\text { (Johnson, 2020) }\end{array}$ & $\begin{array}{l}\text { - Weekly company-wide AMA (Ask } \\
\text { Me Anything) session on Slack or Slido } \\
\text { App where employees submit questions to } \\
\text { leaders (Stillman, 2020) }\end{array}$ \\
\hline Blockchain Technology & $\begin{array}{l}\text { - Increased security to digitally } \\
\text { sign legal documents or contracts } \\
\text { (Gandzeichuk \& Forbes Council, 2020) }\end{array}$ & $\begin{array}{l}\text { Blockchain-powered smart contracts } \\
\text { can be signed remotely without sharing } \\
\text { private information, tracks products } \\
\text { throughout supply chain, may reduce } \\
\text { chances of germ spread on physical } \\
\text { currency (van Hoek \& Lacity, 2020) }\end{array}$ \\
\hline
\end{tabular}

